\title{
Human Monocyte/Macrophage Fungicidal Activity GM-CSF Against Paracoccidioides brasiliensis Depends on ROS
}

\author{
João Paulo Martins do Carmo ${ }^{1 *}$, Luciane Alarcão Dias-Melício², Sueli Aparecida Calvi , Maria Terezinha Serrão \\ Peraçoli $^{4}$ and Ângela Maria Victoriano Campos Soares ${ }^{4}$
}

${ }^{1}$ UEG Campus Itumbiara-GO, Brazil

${ }^{2}$ Department of Pathology, Medicine School of Botucatu (FMB), University of the State of São Paulo (UNESP), Brazil

${ }^{3}$ Department of Infectious Diseases, Medicine School of Botucatu, Brazil

${ }^{4}$ Department of Microbiology and Immunology, Basic Institute of Biosciences (IBB), Brazil

*Corresponding author: João Paulo Martins do Carmo, University of São Paulo, Universidade Estadual de Goiás, Campus Itumbiara-GO, Brazil

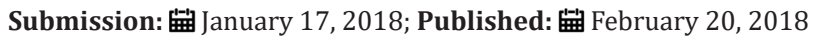

\begin{abstract}
The ability of recombinant human granulocyte-macrophage colony-stimulating factor (GM-CSF) to activate human monocytes/macrophages for virulent Paracoccidioides brasiliensis killing was evaluated. Peripheral blood monocytes (MO) and monocyte-derived macrophages (Mø) were activated with different concentrations of GM-CSF. Afterwards, cells were challenged with P. brasiliensis strain $18(\mathrm{~Pb} 18)$ and the fungicidal activity was evaluated, plating and counting the Colony Forming Units (CFU) after 10 days. GM-CSF activated MO and M $\varnothing$ for $P$. brasiliensis killing in a concentration-dependent manner. There was an association between this fungicidal activity and the high levels of $\mathrm{H}_{2} \mathrm{O}_{2}$ release by the activated cells. Moreover, the killing effect was inhibited by Catalase (CAT), confirming the role of $\mathrm{H}_{2} \mathrm{O}_{2}$ in this process. On the other hand, L-Monomethyl-Arginine (L-NMMA) had no effect on fungicidal activity, showing that nitric oxide (NO) is not involved in killing by human cells against $P$. brasiliensis. Based on these data, the role of GM-CSFactivated human cells in the innate defense mechanisms against $P$. brasiliensis is discussed.
\end{abstract}

Keywords: Paracoccidioidomycosis; Paracoccidioides brasiliensis; Human monocytes; Human macrophages; GM-CSF; Fungicidal activity; $\mathrm{H}_{2} \mathrm{O}_{2} ; \mathrm{NO}$; ROS

\section{Introduction}

Paracoccidioidomycosis (PCM) is the major systemic mycosis in Latin America. Its etiological agent is the fungus Paracoccidioides brasiliensis, a microorganism with thermal dimorphism, behaving as yeast at body temperature [1,2]. This fungus causes a natural infection by inhalation of conidia or mycelial elements which are converted into the parasitic yeast form in lungs [3]. This disease shows multiple shapes, ranging from benign and localized to severe and disseminated ones, depending on many factors, such as the host cell immunity and strain virulence of the fungus [4].

Among the immunological mechanisms reported to this infection, innate immunity monocytes (MO)/macrophages appear to play a fundamental role, acting as the first defense line in the organism [3], depending on their state of activation [5]. Ingested conidia or yeast forms of $P$. brasiliensis readily multiply inside murine alveolar or peritoneal macrophages; however, when cells are activated by cytokines, such as IFN- $\gamma$, the multiplication is limited and conidia or yeast cells may be killed [2,3,6-8].

With regards to murine cells, some studies have shown that IFN- $\gamma$ activation promotes P. brasiliensis killing through the
L-arginine/NO pathway [9]. However, works in our laboratory have demonstrated that IFN- $\gamma$ activation is not enough for the fungicidal activity of human cells against virulent $P$. brasiliensis strain (Pb18) [10]. This process is effective after cells preactivation with TNF- $\alpha$ or IFN- $\gamma$ plus TNF- $\alpha$. Moreover, these studies provided strong evidence of $\mathrm{H}_{2} \mathrm{O}_{2}$ participation as an effector mechanism, since catalase, a $\mathrm{H}_{2} \mathrm{O}_{2}$ scavenger, inhibited the intracellular killing by TNF- $\alpha$ or TNF- $\alpha$ plus IFN- $\gamma$-activated MO [11].

The role of other cytokines, besides IFN- $\gamma$ and TNF- $\alpha$ concerning human $\mathrm{MO} /$ macrophage- $P$. brasiliensis interaction is still unclear. Broad evidence has indicated that GM-CSF not only promotes proliferation and differentiation of hematopoietic precursor cells, but also induces various aspects of macrophage activation [12-16], e.g., respiratory burst activity [15]. MO release Reactive Oxygen Species (ROS, such as $\mathrm{H}_{2} \mathrm{O}_{2}, \mathrm{O}_{2}-$ and $\mathrm{OH}$ ), which are cytotoxic to microorganisms and tumor cells.

The effects of GM-CSF on MO/macrophage function against microbial pathogens have been studied in uncontrolled trials in humans and in vitro and in vivo experiments $[12,13,16]$. 
Enhancement of the microbicidal activity of MO by GM-CSF was shown in vitro against Candida albicans [17], Aspergillus fumigates $[18,19]$, Histoplasma capsulatum [20,21], Cryptococcus neoformans [22], Trypanosoma cruzi [23], Mycobacterium avium [24], M. lepraemurium [25] and M. avium-intracellulare Complex (MAC) [26]. Therefore, we propose that MO/macrophage activation by GM-CSF might be necessary for $P$. brasiliensis killing.

Thus, the aim of this work was to study:

A. The role of GM-CSF on human $\mathrm{MO} /$ macrophage fungicidal activity against a virulent strain of $P$. brasiliensis (Pb18);

B. The involvement of reactive oxygen and nitrogen intermediates in the killing of Pb18 by GM-CSF-activated MO/ macrophages.

\section{Materials and Methods}

\section{Reagents and Media}

Recombinant human GM-CSF was purchased from R\&D Systems, Minneapolis, MN, USA. RPMI 1640 Tissue Culture Medium; Histopaque ( $\mathrm{d}=1.077)$; CAT; L-NMMA; Phorbol-MyristateAcethate (PMA); Sulphanilamide; and Naphtyl Ethylene-DiamineDihydrochloride (NEED) were purchased from Sigma Chemical CO, St. Louis, MO, USA. Complete tissue culture media (CTCM) consisted of RPMI 1640 suplemmented with $10 \%$ (v/l) heat-in activated human $A B$ serum, 20mM HEPES, 2mM of L-glutamine (Gibco Laboratories, Grand Island, NY, USA) and $40 \mu \mathrm{g} / \mathrm{ml}$ of gentamicin.

Brain-Heart Infusion (BHI) agar medium (Difco Laboratories, Detroit, MI, USA), used for culture plating, contained gentamicin 0.5\% (Neoquímica, Anápolis, GO, Brazil), 4\% horse normal serum and $5 \%$ P. brasiliensis strain 192 culture filtrates $(\mathrm{v} / \mathrm{v})$, the latter being the source of growth-promoting factor [27]. 96-well flatbottomed plates were purchased from Nunc, Life Tech. Inc. Maryland, MA, USA. Horseradish peroxidase (type II) was obtained from Sigma Chemical, San Diego, CA, USA. P. brasiliensis strain 18 ( $\mathrm{Pb} \mathrm{18)}$ was maintained in the yeast-form cells at $35{ }^{\circ} \mathrm{C}$ in GPY culture medium for six days [28]. Yeast viability was determined by phase contrast microscopy and bright yeast cells were counted as viable, while dark ones were considered nonviable. Fungal suspensions containing more than $90 \%$ viable cells were used for the experiments.

\section{Donors}

MO was isolated from volunteer healthy blood donors, after informed consent from the University Hospital of the Botucatu Medical School (FMB), São Paulo State University (UNESP, Brazil). The Hospital Ethics Committee approved this study.

Isolation of peripheral blood mononuclear cells (PBMC): PBMC were isolated from heparinized venous blood by density gradient. Briefly, $10 \mathrm{ml}$ of heparinized blood were mixed with an equal volume of complete tissue culture medium (CTCM). Samples were layered over $5 \mathrm{ml}$ of Histopaque in a $15-\mathrm{ml}$ conical plastic centrifuge tube. After centrifugation at $300 \times \mathrm{g}$ for $30^{\prime}$ at room temperature, the interface layer of PBMC was harvested and washed twice with PBS-EDTA and once with CTCM. Cell viability as determined by $0.2 \%$ trypan blue exclusion was $>95 \%$ in all experiments. The MO were stained with neutral red $(0.02 \%)$ and the concentrations were adjusted to $2 \times 10^{6} \mathrm{MO} / \mathrm{ml}$ in CTCM. More than $90 \%$ of the cells were considered as MO by morphological examination, neutral red uptake, and staining for unspecific esterase [29].

\section{MO/macrophage monolayers}

$100 \mu \mathrm{L}$ of MO suspension $\left(2 \times 10^{6} \mathrm{MO} / \mathrm{ml}\right)$ was dispensed into 96 well flat-bottomed plates. After incubation during $2 \mathrm{~h}$ at $37^{\circ} \mathrm{C}$ in $5 \%$ $\mathrm{CO}_{2}$, non adherent cells were removed by aspiration and each well was rinsed twice with CTCM. After adherence, MO were cultured in $\mathrm{CTCM}$ at $37^{\circ} \mathrm{C}$ in $5 \% \mathrm{CO}_{2}$ during $18 \mathrm{~h}$, alone (MO) or containing GMCSF in different concentrations $(1,10,31.25,62.5,125,250,500$ and $1000 \mathrm{U} / \mathrm{mL}$ ). For the MO differentiation process into macrophages, MO cultures were maintained during 7 days in CTCM, changing the culture media every other day and, subsequently activating the cells with GM-CSF (M $\varnothing)$, in diferente concentrations $(1,10,31.25,62.5$, $125,250,500$ and $1000 \mathrm{U} / \mathrm{mL}$ ). In other experiments, MO-derived macrophages were cultured in the presence of GMCSF 250U/mL (G$M \emptyset$ ), changing the culture media every other day, for 7 days. After MO-macrophage differentiation, the supernatants were removed, and cells were activated with GM-CSF in different concentrations $(1,10,31.25,62.5,125,250,500,1000 \mathrm{U} / \mathrm{mL})$ for $18 \mathrm{~h}$.

Fungicidal activity After supernatants removal of control and treated monolayers, MO/macrophages were challenged with 100 $\mu \mathrm{l}$ of $2 \times 10^{4}$ viable units $/ \mathrm{ml}$ of Pb18 (ratio 50:1) in CTCM containing $10 \%$ fresh human $\mathrm{AB}$ serum, in absence or presence of CAT $(20,000 \mathrm{U} / \mathrm{mL})$ or L-NMMA $(450 \mathrm{U} / \mathrm{mL})$. After coculture during $18 \mathrm{~h}$ (experimental cultures), cells were harvested by aspiration with sterile distilled water to lyse MO. Each culture and well washing was contained in a final volume of $2 \mathrm{ml}$. The number of colony forming units (CFU) of $\mathrm{Pb} 18$ per culture was determined by plating $100 \mu \mathrm{l}$ of the 2-ml harvested volume, in triplicate, on BHI containing 4\% normal horse serum and 5\% P. brasiliensis strain 192 culture filtrates (v/v). A control culture only containing $100 \mu \mathrm{l}$ of yeastform $\mathrm{Pb} 18\left(2 \times 10^{4}\right.$ viable units $\left./ \mathrm{ml}\right)$ was submitted to the same procedures used for the experimental cultures. Inoculated plates were incubated at $35{ }^{\circ} \mathrm{C}$ in sealed plastic bags to prevent drying. After 10 days the number of CFU per plate was counted and the percentage of fungicidal activity was determined by the formula: mean CFU of experimental culture

Fungicidal Activity (\%)=1- (mean CFU of experimental culture) mean CFU of control culture

\section{Reactive oxygen intermediates (ROI) determination}

ROI production was indirectly measured by assessing $\mathrm{H}_{2} \mathrm{O}_{2}$ release from MO and macrophages, according to the method previously described by PICK \&KEISARI [30] and adapted by PICK \& MIZEL [31]. MO or MO-derived macrophages were obtained as previously described, and cultured in duplicate in 96-well plates for 24 hours, at $37^{\circ} \mathrm{C}$ in $5 \% \mathrm{CO}_{2}$ tension, with or without $100 \mu \mathrm{L}$ of recombinant human GM-CSF (rh-GM-CSF) $(1,10,31.25,62.5,125$, 
250, 500 and $1000 \mathrm{U} / \mathrm{mL}$ ). After this period, culture supernatants were used to nitric oxide (NO) determination and the adherent cells were resuspended to the original volume $(0,1 \mathrm{~mL})$ in phenol red buffer solution containing: $140 \mathrm{mM}$ of $\mathrm{NaCl} ; 10 \mathrm{nM}$ of phosphate buffer, pH 7; $5.5 \mathrm{mM}$ of dextrosis; $0.56 \mathrm{mM}$ of phenol red; $0.01 \mathrm{mg} /$ $\mathrm{mL}$ of peroxidase from radish peroxidase type II and, in the presence or absence of $1 \mathrm{mg}$ of phorbol myristateacethate (PMA), and were incubated at $37{ }^{\circ} \mathrm{C}$ in a dark, humid chamber. After 60 minutes, the reaction was interrupted by the addition of $0.01 \mathrm{~mL}$ of $\mathrm{NaOH} 1 \mathrm{~N}$. Absorbances were measured at $620 \mathrm{~nm}$ in an automatic ELISA microreader. Results were expressed in nanomols (nM) of $\mathrm{H}_{2} \mathrm{O}_{2} / 2 \times 10^{5}$ cells, using a standard curve.

\section{Reactive nitrogen intermediates (RNI) determination}

NO production was determined based on Griess reaction [32]. Culture supernatants were mixed in with an equal volume of Griess reagent ( $1 \%$ Sulphanilamide, $0.1 \%$ NEED, in 5\% phosphoric acid) at room temperature for $10 \mathrm{~min}$ [32]. Sodium nitrite $\left(\mathrm{NaNO}_{2}{ }^{-}\right)$was used as standard. Absorbances were measured at $540 \mathrm{~nm}$ in an ELISA microreader. Assays were carried out in quadriplicate. Results were expressed in $\mu$ mols of $\mathrm{NO}_{2}-/ 2 \times 10^{5}$ cells, comparing the optical density (OD) with a standard curve of known $\mathrm{NO}_{2}$ - concentrations. Statistical Analysis: Statistical procedures were performed using Graphpad Instat software (San Diego, California - USA). Significant differences among the various groups were detected by Repeated Measures Analysis of Variance (ANOVA), followed by Tukey Kramer Multiple Correlations. Significance level was set at $p<0.05$.

\section{Results}

Role of GM-CSF on human monocyte (MO) fungicidal activity in vitro for high-virulent $P$. brasiliensis killing

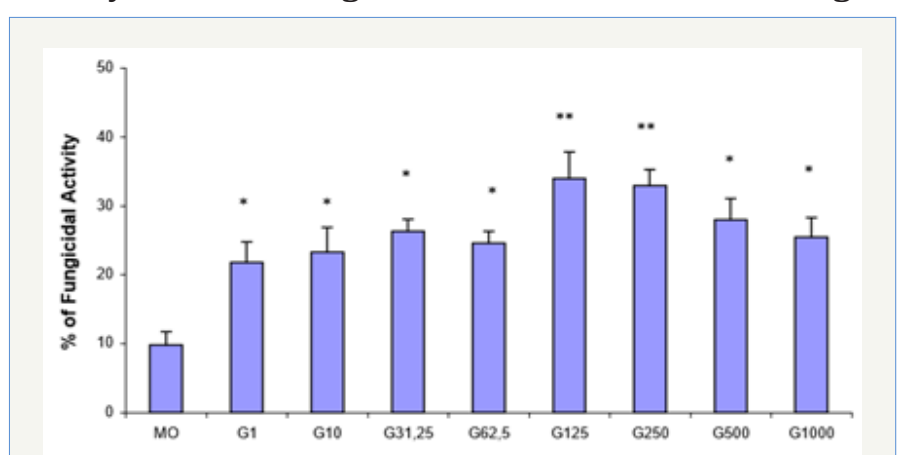

"p<0,05 vs MO, "p<0,01 vs MO

Figure 1: Monocytes $\left(2 \times 10^{6} / \mathrm{mL}\right)$ were preincubated in the absence (MO) or presence of GM-CSF (G) in different concentrations $(1,10,31.25,62.5,125,250$, 500 and $1000 \mathrm{U} / \mathrm{mL}$ ) for $18 \mathrm{~h}$ and challenged with $\mathrm{P}$. brasiliensisduring $4 \mathrm{~h}$ for fungicidal activity in vitro. Results are expressed as Mean $(\mathrm{M}) \pm \mathrm{SEM}$ of 11 subjects.

Figure 1 shows the percentage (\%) of fungicidal activity of MO newly isolated from the peripheral blood of normal donors, incubated only with CTCM (MO) or in the presence of GM-CSF (G) in different doses $(1,10,31.25,62.5,125,250,500$ and 1000U/ $\mathrm{mL}$ ). Preincubation of MO with GM-CSF during $18 \mathrm{~h}$ induces a concentration-dependent increase in the fungicidal activity against high-virulent strain of $P$. brasiliensis (Pb18). Significant fungicidal activity was detected in every concentration of GM-CSF, and maximal activity occurred with the doses of 125 (33.9\%) and $250 \mathrm{U} / \mathrm{mL}(32.9 \%)$.

\section{Role of CAT and L-NMMA on fungicidal activity of GM- CSF-activated MO}

Role of CAT and L-NMMA on fungicidal activity of GM-CSFactivated MO To detect the effector mechanisms involved in GM-CSF-activated MO for $P$. brasiliensis killing, cocultures of MO were challenged with $\mathrm{Pb} 18$ and treated concomitantly with CAT $(20,000 \mathrm{U} / \mathrm{mL})$, a scavenger of $\mathrm{H}_{2} \mathrm{O}_{2}$ production; or L-NMMA (450U/ $\mathrm{mL}$ ), a competitive inhibitor of nitric oxide synthase (NOS), the enzyme responsible for NO production. Results showed that CAT inhibited the fungicidal activity presented by GM-CSF-activated MO, indicating the role of $\mathrm{H}_{2} \mathrm{O}_{2}$ in this process. On the other hand, L-NMMA did not show a significant effect (Figure 2).

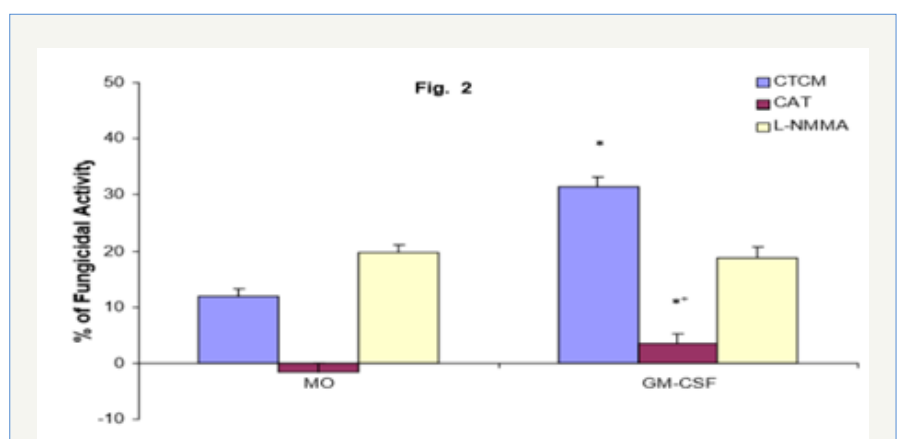

$-p<0,05$ vs MO, +p<0,05 vs MO+OM-C sF

Figure 2: Monocytes $\left(2 \times 10^{6} / \mathrm{mL}\right)(\mathrm{MO})$ activated with GM$\mathrm{CSF}(125 \mathrm{U} / \mathrm{mL})$ during $18 \mathrm{~h}$ were incubated in the absence or presence of CAT $(20,000 \mathrm{U} / \mathrm{mL})$ or L-NMMA $(450 \mathrm{U} / \mathrm{mL})$, challenged concomitantly with P. brasiliensis during $4 \mathrm{~h}$, and assessed for fungicidal activity in vitro. Results are expressed as Mean $(\mathrm{M}) \pm$ SEM of 11 subjects.

As shown in Table $1, \mathrm{H}_{2} \mathrm{O}_{2}$ levels were significantly diminished after non activated $\mathrm{MO}$ challenge with $\mathrm{Pb} 18(\mathrm{MO}+\mathrm{Pb}=0.81 \pm 0.24 \mathrm{nM})$, when compared to non-activated MO alone $(\mathrm{MO}=1.97 \pm 0.53 \mathrm{nM})$. However, when MO were pre activated with GM-CSF, a significant increase in $\mathrm{H}_{2} \mathrm{O}_{2}$ production was detected (MO+GM$\mathrm{CSF}=3.13 \pm 0.63 \mathrm{nM}$ ), when compared to $\mathrm{MO}$ or $\mathrm{MO}+\mathrm{Pb}$. Moreover, in MO pre activated with GM-CSF and challenged with $\mathrm{Pb} 18$ (MO+GM$\mathrm{CSF}+\mathrm{Pb}=2.88 \pm 0.52 \mathrm{nM}), \mathrm{H}_{2} \mathrm{O}_{2}$ levels were like those detected in MO+GM-CSF cultures. These data show that, differently of non activated MO challenged with $\mathrm{Pb} 18(\mathrm{MO}+\mathrm{Pb})$, the challenge of GMCSF pre activated cells with $\mathrm{Pb}(\mathrm{MO}+\mathrm{GM}-\mathrm{CSF}+\mathrm{Pb})$ did not result in $\mathrm{H}_{2} \mathrm{O}_{2}$ inhibition. In addition, all the cocultures treated with CAT $(\mathrm{MO}+\mathrm{CAT}, \mathrm{MO}+\mathrm{GM}-\mathrm{CSF}+\mathrm{CAT}, \mathrm{MO}+\mathrm{Pb}+\mathrm{CAT})$ showed a significant inhibition in $\mathrm{H}_{2} \mathrm{O}_{2}$ levels, compared to those detected in absence of this scavenger. Concerning $\mathrm{NO}_{2}$ - production, similarly to $\mathrm{H}_{2} \mathrm{O}_{2}$ release, in cocultures supernatants of $\mathrm{MO}+\mathrm{Pb}(=1.46 \pm 0.49 \mu \mathrm{M})$, we detected a significant inhibition in this metabolite production, compared to $\mathrm{MO}(=2.38 \pm 0.75)$. However, conversely to $\mathrm{H}_{2} \mathrm{O}_{2}$, GMCSF $(2.54 \pm 0.69 \mu \mathrm{M})$ did not stimulate the cells to increase $\mathrm{NO}_{2}$ - 
production, when compared to MO. Moreover, $\mathrm{MO}+\mathrm{GM}-\mathrm{CSF}+\mathrm{Pb}$ did not release higher levels of $\mathrm{NO}_{2}-$.

Together, the results showed that $\mathrm{NO}_{2}$ - levels were very low in all cocultures supernatants, suggesting no correlation with fungicidal activity. The lack of L-NMMA effect on fungicidal activity of MO+GM-CSF reinforces these results. Results shown in Figure 1 \& 2 and Table 1 suggest that the fungicidal activity presented by GM-CSF-activated MO is mediated by $\mathrm{H}_{2} \mathrm{O}_{2}$, while NO seems not to be involved.

Table 1: Production of $\mathrm{H}_{2} \mathrm{O}_{2}$ and $\mathrm{NO}_{2}$ - in cocultures of MOpreactivated with GM-CSF $(125 \mathrm{U} / \mathrm{mL})$ for $18 \mathrm{~h}$, before the challenge with $P$. brasiliensis during $4 \mathrm{~h}$, in absence or presence of scavenger of $\mathrm{H}_{2} \mathrm{O}_{2}$ release (CAT) or inhibitor of NO production (L-NMMA). Results are expressed as $\mathrm{M} \pm \mathrm{SEM}$ of 8 experiments.

\begin{tabular}{|c|c|c|}
\hline Monocytes treatment & $\begin{array}{c}\mathrm{H}_{2} \mathrm{O}_{2} \text { release } \\
\text { (nmoles } / 2 \times 10^{5} \text { cells) }\end{array}$ & $\begin{array}{c}\mathrm{NO}_{2}{ }^{\prime} \text { release } \\
\text { ( } \mu \text { moles } / 2 \times 10^{5} \text { cells) }\end{array}$ \\
\hline MO & $1.97 \pm 0.43$ & $2.38 \pm 0.75$ \\
\hline MO+ CAT/L-NMMA* & $0.55 \pm 0.12$ & $1.64 \pm 0.45+\bullet$ \\
\hline $\mathrm{MO}+\mathrm{Pb}$ & $0.81 \pm 0.24+$ & $1.46 \pm 0.49+$ \\
\hline$M O+P b+C A T / L-N M M A$ & $0.34 \pm 0.08$ & $1.19 \pm 0.31+\bullet$ \\
\hline $\mathrm{MO}+\mathrm{GM}-\mathrm{CSF}$ & $3.13 \pm 0.63+\bullet$ & $2.54 \pm 0.69$ \\
\hline$M O+$ GM-CSF + CAT/L-NMMA & $0.92 \pm 0.46$ & $1.84 \pm 0.51+\bullet$ \\
\hline $\mathrm{MO}+\mathrm{GM}-\mathrm{CSF}+\mathrm{Pb}$ & $2.88 \pm 0.52+\bullet$ & $1.39 \pm 0.52+$ \\
\hline $\mathrm{MO}+\mathrm{GM}-\mathrm{CSF}+\mathrm{Pb}+\mathrm{CAT} / \mathrm{L}-\mathrm{NMMA}$ & $1.12 \pm 0.44 \bullet$ & $1.16 \pm 0.39+\bullet$ \\
\hline \multicolumn{3}{|c|}{ 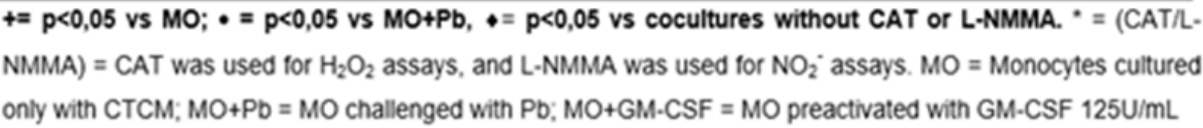 } \\
\hline
\end{tabular}

Role of GM-CSF on the fungicidal activity of human MOderived macrophages cultured in CTCM for 7 days in vitro $(\mathrm{M} \varnothing)$

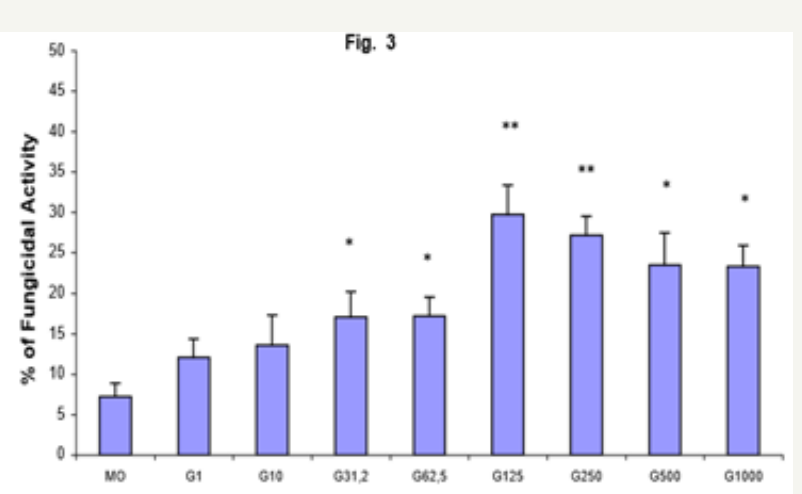

" p<0,05 vs Mव, " p<0,01 vs Mə

Figure 3: Monocyte-derived macrophages $\left(2 \times 10^{6} / \mathrm{mL}\right)$ incubated with CTCM for 7 days $(\mathrm{M} \emptyset)$ were activated with different GM-CSF (G) concentrations $(1,10,31.25,62.5$, $125,250,500$ and $1000 \mathrm{U} / \mathrm{mL}$ ) during $18 \mathrm{~h}$. Following, they were challenged with $\mathrm{P}$. brasiliensisduring $4 \mathrm{~h}$ and assessed for fungicidal activity in vitro. Results are expressed as Mean $(\mathrm{M}) \pm \mathrm{SEM}$ of 8 subjects.

Similarly, the data obtained with MO pre incubation, GM-CSF activated macrophages $(\mathrm{M} \varnothing)$ displayed a dose-dependent increase in fungicidal activity, from $31.25 \mathrm{U} / \mathrm{mL}$ (15.5\%), to the most significant concentrations of 125 and $250 \mathrm{U} / \mathrm{mL}$ (29.8\% and 27.2\%, respectively), when compared to control $\mathrm{M} \varnothing$ (7.2\%). It shall be reinforced that, compared to MO (Figure 1; 33.9 and 32.9\%), the activity of activated-M $\varnothing$ was not statistically significant.
Role of CAT and L-NMMA on fungicidal activity of GMCSF-activated GM $\varnothing$

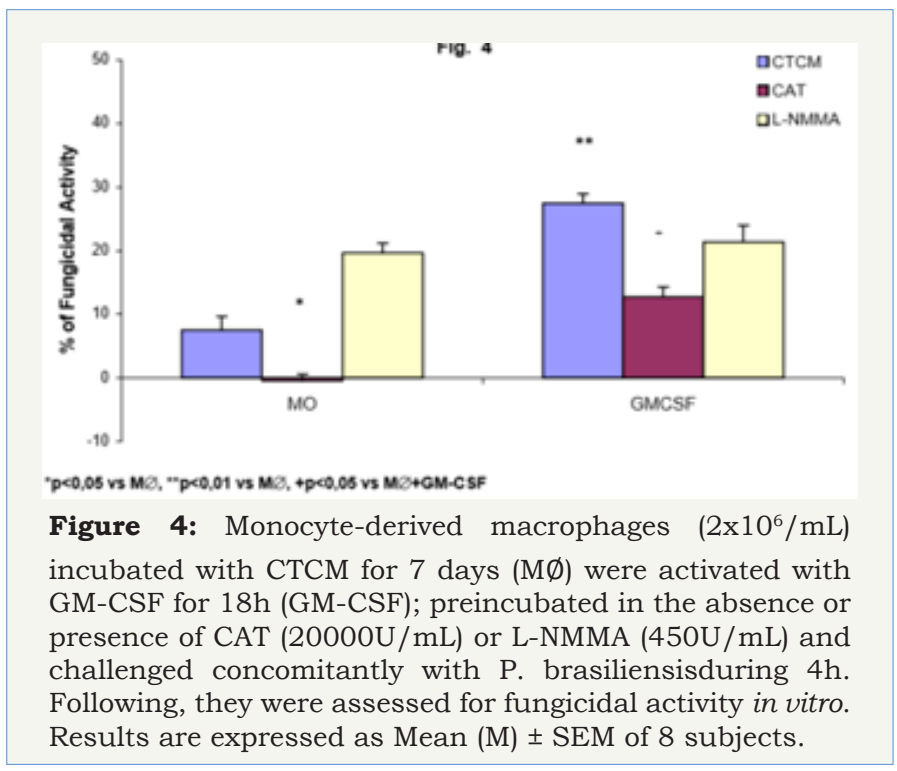

To detect the effector mechanisms involved in GM-CSFactivated macrophages $(\mathrm{M} \emptyset)$ for P. brasiliensis killing, we challenged these cocultures with $\mathrm{Pb} 18$ and treated them concomitantly with CAT or L-NMMA. Similarly to MO cultures (MO-Figure 2), CAT inhibited the fungicidal activity induced by GM-CSF, confirming the role of $\mathrm{H}_{2} \mathrm{O}_{2}$ in this process, as well with $\mathrm{M} \varnothing$. On the other hand, LNMMA did not change fungicidal activity of GMCSF-activated $M \emptyset$, like in MO cultures (Figure 4). One may see in Table 2 that the levels of $\mathrm{H}_{2} \mathrm{O}_{2}$ were significantly diminished after non activated macrophages challenge with $\mathrm{Pb} 18(\mathrm{M} \emptyset+\mathrm{Pb}=0.71 \pm 0.23 \mathrm{nM})$, when compared to macrophages alone $(\mathrm{M} \emptyset=1.24 \pm 0.53 \mathrm{nM})$. However, 
when macrophages were pre activated with GM-CSF $(\mathrm{M} \emptyset+\mathrm{GM}$ $\mathrm{CSF}=2.33 \pm 0.64 \mathrm{nM}$ ), a significant increase in $\mathrm{H}_{2} \mathrm{O}_{2}$ production was detected, when compared to $\mathrm{M} \emptyset$ or $\mathrm{M} \emptyset+\mathrm{Pb}$.

Macrophages preactivated with GM-CSF and challenged with $\mathrm{Pb}$ showed similar $\mathrm{H}_{2} \mathrm{O}_{2}$ levels $(\mathrm{M} \emptyset+\mathrm{GM}-\mathrm{CSF}+\mathrm{Pb}=2.17 \pm 0.6 \mathrm{nM}$ ) to those detected in $\mathrm{M} \varnothing+\mathrm{GM}$-CSF culture. These data show that, differently of non-activated $\mathrm{M} \varnothing$ challenged with $\mathrm{Pb} 18(\mathrm{M} \emptyset+\mathrm{Pb})$, the challenge of activated cells $(\mathrm{M} \emptyset+\mathrm{GMCSF}+\mathrm{Pb})$ did not lead to $\mathrm{H}_{2} \mathrm{O}_{2}$ inhibition. In all the cocultures treated with CAT, a significant inhibition in $\mathrm{H}_{2} \mathrm{O}_{2}$ levels was obtained, compared to those detected in the absence of this scavenger. In relation to $\mathrm{NO}_{2}$-, similarly to $\mathrm{H}_{2} \mathrm{O}_{2}$ release and also similarly to MO cultures, there was a significant inhibition in this metabolite production in cocultures supernatants of $\mathrm{M} \emptyset+\mathrm{Pb} \quad(=2.46 \pm 0.53 \mu \mathrm{M})$, compared to $\mathrm{M} \emptyset$ $(=3.17 \pm 0.98)$. However, conversely to $\mathrm{H}_{2} \mathrm{O}_{2}, \mathrm{GM}-\mathrm{CSF}(3.03 \pm 0.91 \mu \mathrm{M})$ did not stimulate the cells to increase NO2-production, compared to $\mathrm{M} \emptyset$. Moreover, $\mathrm{M} \emptyset+\mathrm{GM}-\mathrm{CSF}+\mathrm{Pb}(1.89 \pm 0.39)$ did not release higher levels of $\mathrm{NO}_{2}$. Once more, as occurred in supernatants of $\mathrm{MO}$ cultures, the results showed that $\mathrm{NO}_{2}$ - levels were very low in all cocultures supernatants, suggesting that they were not correlated with fungicidal activity. Again, these results are associated with the lack of L-NMMA effect on fungicidal activity presented by GM-CSFactivated $\mathrm{M} \emptyset$. Together, the results presented in Table 2 and Figure S3 \& 4 showed that the fungicidal activity presented by GM-CSFactivated $\mathrm{M} \varnothing$ is mediated by $\mathrm{H}_{2} \mathrm{O}_{2}$, similarly to MO experiments. In experiments with $\mathrm{M} \emptyset$, once more, NO seems not to be involved.

Table 2: Production of $\mathrm{H}_{2} \mathrm{O}_{2}$ and $\mathrm{NO}_{2}$ - in cocultures of MO-derived macrophages (M $\varnothing$ ), preactivated with GM-CSF (125U/mL) for $18 \mathrm{~h}$ before the challenge with $P$. brasiliensis during $4 \mathrm{~h}$, in absence or presence of scavenger of $\mathrm{H}_{2} \mathrm{O}_{2}$ (CAT) or inhibitor of NO (L-NMMA) release. Results are expressed as $\mathrm{M} \pm \mathrm{SEM}$ of 8 experiments.

\begin{tabular}{|c|c|c|}
\hline Monocytes treatment & $\begin{array}{c}\mathrm{H}_{2} \mathrm{O}_{2} \text { release } \\
\text { (nmoles } / 2 \times 10^{5} \text { cells) }\end{array}$ & $\begin{array}{c}\mathrm{NO}_{2} \text { release } \\
\text { ( } \mu \text { moles } / 2 \times 10^{5} \text { cells) }\end{array}$ \\
\hline$M D$ & $1.34 \pm 0.53$ & $3.17 \pm 0.98$ \\
\hline$M D+$ CAT/L-NMMA* & $0.91 \pm 0.31+\bullet$ & $1.94 \pm 0.47+\bullet$ \\
\hline$M \varnothing+\mathrm{PD}$ & $0.71 \pm 0.23+$ & $2.46 \pm 0.53+$ \\
\hline$M \varnothing+P b+C A T / L-N M M A$ & $0.39 \pm 0.12+\bullet$ & $1.42 \pm 0.41 b+\bullet$ \\
\hline$M \varnothing+\mathrm{GM} \cdot \mathrm{CSF}$ & $2.33 \pm 0.64+\bullet$ & $3.03 \pm 0.91$ \\
\hline$M \varnothing+G M \cdot C S F+C A T / L-N M M A$ & $1.02 \pm 0.36$ & $2.1 \pm 0.44 a+\bullet$ \\
\hline$M \sigma+G M \cdot C S F+P D$ & $2.17 \pm 0.6+\bullet$ & $1.89 \pm 0.39+$ \\
\hline$M \varnothing+G M \cdot C S F+P D+C A T / L-N M M A$ & $0.89 \pm 0.27+\bullet$ & $1.22 \pm 0.27+\bullet$ \\
\hline \multicolumn{3}{|c|}{ 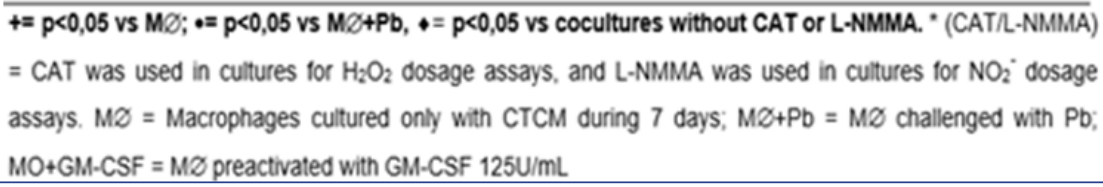 } \\
\hline
\end{tabular}

Role of GM-CSF on the fungicidal activity of human MOderived macrophages, after 7 days of culture in the presence of GM-CSF in vitro (GM $\varnothing$ )

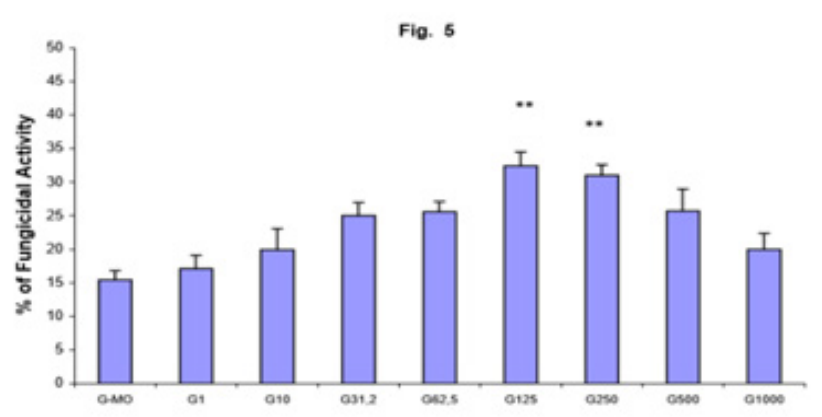

Figure 5: Monocyte-derived macrophages $\left(2 \times 10^{6} / \mathrm{mL}\right)$ by incubation in the presence of GM-CSF for 7 days (G-M $\varnothing$ ) were activated with GM-CSF $(\mathrm{G})$ in different concentrations $(1,10,31,25,62,5,125,250,500$ and $1000 \mathrm{U} / \mathrm{mL})$ for $18 \mathrm{~h}$. Following, they were challenged with P. brasiliensisduring $4 \mathrm{~h}$ and assessed for fungicidal activity in vitro. Results are expressed as Mean (M) \pm SEM of 8 subjects.
Figure 5 shows an increased fungicidal activity of human MO-derived macrophages activated with GM-CSF, after 7 days of treatment in the presence of this cytokine (G-M $\varnothing$ ), only with 125 and $250 \mathrm{U} / \mathrm{mL}$ (32.4\% and $31.0 \%$, respectively), in a similar way compared to fungicidal activity presented by GMCSF-activated-MO and $\mathrm{M} \emptyset$. One may observe that the MO differentiation process into macrophages in the presence of GM-CSF, did not change significantly the responsiveness to GM-CSF pre activation, compared to macrophages culture without this cytokine.

\section{Role of CAT and L-NMMA on fungicidal activity of GM-CSF activated GM $\varnothing$}

As previous assays with $\mathrm{MO}$ and $\mathrm{M} \emptyset$, we attempted to detect the effector mechanisms involved in GM-CSF-activated G-M $\varnothing$ for P. brasiliensis killing, Figure 6 shows that, similarly to MO (Figure 2) and macrophage in absence of GMCSF (M $\varnothing$ - Figure 4) cultures, CAT inhibited the fungicidal activity presented by GMCSF-activated G-M $\varnothing$, reinforcing the role of $\mathrm{H}_{2} \mathrm{O}_{2}$ as well in this process. Once again, L-NMMA could not abrogate fungicidal activity of G-M $\varnothing$ or GM-CSF activated G-M $\emptyset$, as verified in cells treatment with CAT (Figure 6).

As seen in Table $3, \mathrm{H}_{2} \mathrm{O}_{2}$ levels were significantly diminished after $\mathrm{G}-\mathrm{M} \varnothing$ challenge with $\mathrm{Pb} 18 \quad(\mathrm{G}-\mathrm{M} \emptyset+\mathrm{Pb}=0.82 \pm 0.24 \mathrm{nM})$, 
when compared to G-M $\varnothing$ alone ( $\mathrm{G}-\mathrm{M} \emptyset=1.82 \pm 0.63 \mathrm{nM}$ ). However, when G-M $\varnothing$ were pre activated with GM-CSF (G-M $\varnothing+\mathrm{GM}$ $\mathrm{CSF}=3.71 \pm 0.94 \mathrm{nM}$ ), a significant increase in $\mathrm{H}_{2} \mathrm{O}_{2}$ production was detected. In G-Møpreactivated with GM-CSF and challenged with $\mathrm{Pb}(\mathrm{G}-\mathrm{M} \emptyset+\mathrm{GMCSF}+\mathrm{Pb}=2.83 \pm 0.73 \mathrm{nM})$, the $\mathrm{H}_{2} \mathrm{O}_{2}$ levels were similar to that detected in GM $\varnothing+\mathrm{GM}-\mathrm{CSF}$ cultures. These data show that, differently of nonactivated G-M $\varnothing$ challenged with $\mathrm{Pb}(\mathrm{G}-\mathrm{M} \varnothing+\mathrm{Pb})$, the challenge of activated cells with $\mathrm{Pb}(\mathrm{GM} \emptyset+\mathrm{GM}-\mathrm{CSF}+\mathrm{Pb})$ did not lead to $\mathrm{H}_{2} \mathrm{O}_{2}$ inhibition. In all the cocultures treated with CAT, a significant inhibition in $\mathrm{H}_{2} \mathrm{O}_{2}$ levels was observed, compared to the ones detected in absence of this scavenger.

Table 3: Production of $\mathrm{H}_{2} \mathrm{O}_{2}$ and $\mathrm{NO}_{2}$ - in cocultures of MO-derived macrophages in the presence of GM-CSF for 7 days (G-M $\varnothing$ ), preactivated with GM-CSF $(125 \mathrm{U} / \mathrm{mL})$ for $18 \mathrm{~h}$ before the challenge with $P$. brasiliensis during $4 \mathrm{~h}$, in absence or presence of scavenger of $\mathrm{H}_{2} \mathrm{O}_{2}$ (CAT) or inhibitor of NO (LNMMA) release. Results are expressed as M \pm SEM of 8 experiments.

\begin{tabular}{|c|c|c|}
\hline Monocytes treatment & $\begin{array}{c}\mathrm{H}_{2} \mathrm{O}_{2} \text { release } \\
\text { (nmoles } / 2 \times 10^{5} \text { cells) }\end{array}$ & $\begin{array}{c}\mathrm{NO}_{2}{ }^{-} \text {release } \\
\left(\mu \text { moles } / 2 \times 10^{5} \text { cells }\right)\end{array}$ \\
\hline G-MO & $1.82 \pm 0.63$ & $2.93 \pm 1.05$ \\
\hline G-M $\varnothing+$ CAT/L-NMMA & $0.41 \pm 0.17+\bullet$ & $1.35 \pm 0.85+\bullet$ \\
\hline $\mathrm{G}-\mathrm{M} \varnothing+\mathrm{Pb}$ & $0.82 \pm 0.24+$ & $1.23 \pm 0.71+$ \\
\hline $\mathrm{G}-\mathrm{M} \varnothing+\mathrm{PD}+\mathrm{CAT} / \mathrm{L}-\mathrm{NMMA}$ & $0.31 \pm 0.12+\bullet$ & $0.77 \pm 0.25+\bullet$ \\
\hline G-Mø + GM-CSF & $3.71 \pm 0.94+\bullet$ & $3.22 \pm 0.97$ \\
\hline G-Mø + GM-CSF + CAT/L-NMMA & $2.14 \pm 0.6 \bullet$ & $2.74 \pm 0.89 \bullet$ \\
\hline$G-M \varnothing+G M-C S F+P b$ & $2.83 \pm 0.73+\bullet$ & $0.97 \pm 0.21+$ \\
\hline $\mathrm{G}-\mathrm{M} \varnothing+\mathrm{GM}-\mathrm{CSF}+\mathrm{PD}+\mathrm{CAT} / \mathrm{L}-\mathrm{NMMA}$ & $1.68 \pm 0.13 \bullet$ & $1.21 \pm 0.4+\bullet$ \\
\hline \multicolumn{3}{|c|}{$\begin{array}{l}+=\mathrm{p}<0,05 \text { vs } \mathrm{M} \varnothing ; \bullet=\mathrm{p}<0,05 \text { vs } \mathrm{M} \varnothing+\mathrm{Pb}, \bullet=\mathrm{p}<0,05 \mathrm{vs} \text { cocultures without CAT or L-NMMA. }{ }^{*}(\mathrm{CAT} / \mathrm{L}-\mathrm{NMMA}) \\
=\mathrm{CAT} \text { was used in cultures for } \mathrm{H}_{2} \mathrm{O}_{2} \text { dosage, and L-NMMA was used in cultures for } \mathrm{NO}_{2}{ }^{-} \text {dosage. G-M } \varnothing= \\
\text { Macrophages cultured in CTCM+GM-CSF } 250 \mathrm{U} / \mathrm{mL} \text { during } 7 \text { days; G-M } \varnothing+\mathrm{Pb}=\mathrm{G}-\mathrm{M} \varnothing \text { challenged with } \mathrm{Pb} ; \mathrm{G}- \\
\mathrm{M} \varnothing+\mathrm{GM}-\mathrm{CSF}=\mathrm{G}-\mathrm{M} \varnothing \text { preactivated with GM-CSF } 125 \mathrm{U} / \mathrm{mL}\end{array}$} \\
\hline
\end{tabular}

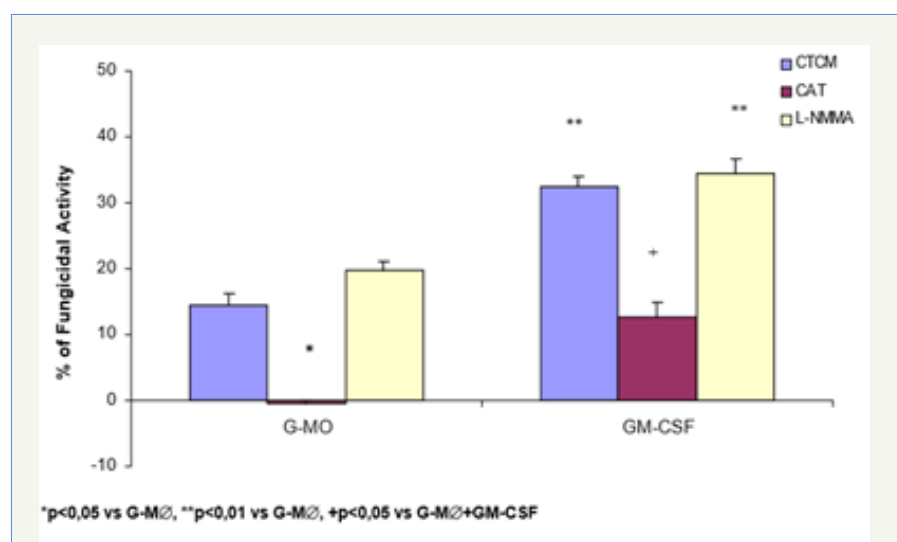

Figure 6: Monocyte-derived macrophages $\left(2 \times 10^{6} / \mathrm{mL}\right)$ by incubation with GM-CSF $250 \mathrm{U} / \mathrm{mL}$ for 7 days (G-M $\emptyset$ ) were activated with GM-CSF $125 \mathrm{U} / \mathrm{mL}$ by $18 \mathrm{~h}$ and preincubated in the presence of scavengers, CAT $(20000 \mathrm{U} / \mathrm{mL})$ or L-NMMA $(450 \mathrm{U} / \mathrm{mL})$, challenged concomitantly with $\mathrm{P}$. brasiliensisduring $4 \mathrm{~h}$, and assessed for fungicidal activity in vitro. The results are expressed as Mean $(\mathrm{M}) \pm \mathrm{SEM}$ of 8 subjects.

As to $\mathrm{NO}_{2}^{-}$, similarly to $\mathrm{H}_{2} \mathrm{O}_{2}$ release and similarly to $\mathrm{MO}$ and $\mathrm{M} \varnothing$ cultures, in cocultures supernatants of $\mathrm{M} \emptyset+\mathrm{Pb}(=2.46 \pm 0.53 \mu \mathrm{M})$, we detected a significant inhibition in this metabolite production, compared to $\mathrm{M} \varnothing(=3.17 \pm 0.98)$. However, conversely to $\mathrm{H}_{2} \mathrm{O}_{2^{\prime}}$ $\mathrm{M} \emptyset+\mathrm{GM}-\mathrm{CSF}(3.03 \pm 0.91 \mu \mathrm{M})$ did not stimulate the cells for increased $\mathrm{NO}_{2}$ - production, compared to $\mathrm{M} \emptyset$. Moreover, $\mathrm{M} \emptyset+\mathrm{GM}-\mathrm{CSF}+\mathrm{Pb}$ $(1.89 \pm 0.39)$ did not release higher levels of $\mathrm{NO}_{2}-$, which were very low in all cocultures supernatants, suggesting that they were not correlated with fungicidal activity. Once again, these results are associated with the lack of L-NMMA effect on fungicidal activity of
MO+GM-CSF cells. Therefore, it follows, from the results shown in Table 3 and Figure $5 \&$ 6, that the fungicidal activity presented by GM-CSF-activated G-M $\varnothing$ is mediated by $\mathrm{H}_{2} \mathrm{O}_{2}$ similarly to $\mathrm{MO}$ and Mø. Again, NO seems not to be involved.

\section{Discussion}

The aim of this work was to investigate the role of GM-CSF on human mononuclear phagocytes activation and the effector mechanisms developed by these cells for $P$. brasiliensis killing. The results presented here allow us to consider the existence of an important fungicidal activity of GM-CSF-activated human MO and MO-derived macrophages against $P$. brasiliensis. Stimulation of MO/macrophage for antimicrobial activity by GM-CSF is reported by a number of studies in vivo and in vitro, evidenciating that this cytokine activates neutrophils, MO and macrophages, and enhances the ability of these cells to kill intracellular parasites, such as Candida albicans [17], Aspergillus fumigates [18,19], Histoplasma capsulatum [20,21], Trypanosoma cruzi [23], Mycobacterium avium [24]; M. lepraemurium [25], and MAC [26]. Since GM-CSF increased the fungicidal activity of human MO and macrophages against $P$. brasiliensis strain 18 (Pb18), we were interested in clarifying the mechanisms by which the cells would exert this activity.

Our results clearly demonstrated that CAT inhibited the fungicidal activity of the cells tested. Moreover, despite of the Pb18 inhibits $\mathrm{H}_{2} \mathrm{O}_{2}$ release, as shown in previous works [33], when the cells are activated by GM-CSF, a compensatory effect on this production was detected, and $\mathrm{H}_{2} \mathrm{O}_{2}$ concentrations were enough for a fungicidal effect. Thus, this work provides evidence that the mechanism by which GM-CSF activated cells kill P. brasiliensis is 
mediated by $\mathrm{H}_{2} \mathrm{O}_{2}$. Previous works in our laboratory [11] showed that this metabolite is also effective in P. brasiliensis killing for IFN- $\gamma$ and TNF- $\alpha$-activated human phagocytes, similarly to other microorganisms $[17,20,23,34,35]$. On the other hand, our results indicate that $\mathrm{NO}$ is not involved in $\mathrm{Pb} 18$ killing by human phagocytic cells, since L-NMMA did not revert the fungicidal activity presented by phagocytes and $\mathrm{NO}_{2}$ - levels in all cocultures were very low, including the ones pre activated with GM-CSF. Production of NO and subsequent formation of peroxynitrite [36] have been found to be a potent antifungal mechanism of mononuclear cells [36-38].

This mechanism has been shown to be efficient in the inhibition of replication and killing of fungi [9,39] and other microorganisms by murine mononuclear phagocytes. Previous results from our group have demonstrated that killing of Pb18 by IFN- $\gamma$ and TNF- $\alpha$ activated peritoneal murine macrophages is mediated by $\mathrm{NO}$ and $\mathrm{H}_{2} \mathrm{O}_{2}$ [40]. Although it is known that $\mathrm{NO}$ is abundantly synthesized by phagocytes from mice and rats, its secretion by human mononuclear phagocytes has become a controversial issue [24,37,40,41]. Mac Micking et al. [40] and Albina [42] have reported that human MO/ macrophages express nitric oxide synthase type II $\left(\mathrm{NOS}_{2}\right)$ as protein synthesis, in response to various stimuli. Furthermore, while it has been found to be a potent antifungal compound of phagocytes in mice, its antifungal role has not been established in human [3739]. Specifically, in this work, NO does not appear to be involved in the fungicidal activity of human phagocytes against $\mathrm{Pb} 18$ yeasts $[43,44]$.

\section{References}

1. Franco M, Mendes RP, Moscardi Bacchi M, Rezkallah Iwasso MT, Montenegro MR, et al. (1989) Paracoccidioidomycosis Bailliere's. Clin Trop Med Commun Dis 4: 185-220.

2. San Blás F, San-Blás G (1985) Paracoccidioides brasiliensis. In: San Blás F, San Blás G (Eds.), PJ Fungal Dimorphism. Plenunm, New York, USA, pp. 93-120.

3. Brummer E, Sun SH, Harrison JL, Perlman AM, Philpott DE, et al. (1990) Ultraestucture of phagocytosed Paracoccidioides brasiliensis in nonactivated or activated macrophages. Infect Immun 58: 2628-2634.

4. Restrepo A (1985) The ecology of Paracoccidioides brasiliensis: a puzzle still unsolved. Sabouraudia 23(5): 323-334.

5. Moonis M, Ahmad I, Bochhowot BW (1992) Macrophages in host defence- An overview. Indian J Biochem Biophys 29(2): 115-122.

6. Brummer E, Hanson LH, Stevens DA (1988) In vivo and in vitro activation of pulmonary macrophages by IFN- $\gamma$ for enhanced killing of Paracoccidioides brasiliensis and Blastomycesdermatitidis. J Immunol 140(8): 2786-2789.

7. Brummer E, Hanson LH, Stevens DA (1988) Gamma-interferon activation of macrophages for killing of Paracoccidioides brasiliensis and evidence for nonoxidative mechanisms. Int J Immunopharmacol 10(8): 945-952.

8. Brummer E, Hanson LH, Restrepo A, Stevens DA (1989) Intracellular multiplication of Paracoccidioides brasiliensis in macrophages: Killing and restriction of multiplication by activated macrophages. Infect Immun 57(8): 2289-2294.

9. Gonzalez A, Gregori W, Velez D, Restrepo A, Cano L, et al. (2000) Nitric oxide participation in the mechanism of gamma-interferon-activated murine macrophages against Paracoccidioides brasiliensis. Infec Immun 68(5): 2546-2552
10. Calvi Sa, Peraçoli Mts, Mendes Rp, Machado Jm, Fecchio D, et al. (2003) Effect of cytokines on the in vitro fungicidal activity of monocytes from paracoccidioidomycosis patients. Microbes Infect 5(2): 107-113.

11. Carmo JP, LA Dias Melício, Calvi, SA, Peraçoli MTS, Soares, AMVC (2006). TNF-alpha activates human monocytes for Paracoccidioides brasiliensis killing by an $\mathrm{H}_{2} \mathrm{O}_{2}$-dependent mechanism. Med Mycol 44(4): 363-368.

12. Armitage JO (1998) Emerging applications of recombinant human Granulocyte Macrophage Colony-Stimulating Factor. Blood 92(12): 4491-4508.

13. Jones TC (1999) Use of Granulocyte-macrophage Colony Stimulating Factor (GMCSF) in prevention and treatment of fungal infections. Eur J Canc 35(3): S8-S10.

14. Williams MA, Kelsey SM, Newland AC (1999) Gm-Csf and stimulation of monocyte/macrophage function. In vivo relevance and in vitro observations. Eur J Canc 35(3): S18-S22.

15. Williams MA, Kelsey SM, Collin PW, Gutteridge CN (1995) Newland Ac. Administration of rHuGM-CSF activates monocyte reactive oxygen species secretion and adhesion molecule expression in vivo in patients following high-dose chemotherapy. Br J Haematol 90(1): 31-38.

16. Gasson JC (1991) Molecular phisiology of granulocyte-macrophage colonystimulating factor. Blood 77(6): 1131-1150.

17. Smith PD, Lamerson CL, Banks SM, Saini SS, Wahl LM, et al. (1990) Granulocyte-macrophage colony-stimulating factor augments human monocyte fungicidal activity for Candida albicans. J Inf Dis 161(5): 9991005 .

18. Rolides E, Sein T, Holmes A, Blake C, Pizzo PA, et al. (1995) Effects of macrophage colony-stimulating factor on antifungal activity of mononuclear phagocytes against Aspergillus fumigatus. J Inf Dis 172(4): 1028-1134.

19. Roilides E, Blake C, Holmes A, Pizzo PA, Walsh TJ, et al. (1996) Granulocytemacrophage colony-stimulating factor and IFN- $\gamma$ prevent dexamethasonne-induced immunosuppression of antifungal monocyte activity against Aspergillus fumigatus hyphae. Journal of Medical and Veterinary Mycology 34(1): 63-69.

20. Newman SL, Gootee L (1992) Colony-stimulating factors activate human macrophages to inhibit intracellular growth of Histoplasma capsulatum yeasts. Infect Immun 60(11): 4593-4600.

21. Deepe JR, Gibbons R, Woodward E (1999) Neutralization of endogenous Granulocyte-Macrophage Colony-Stimulating Factor subverts the protective immune response to Histoplasma capsulatum. J Immun 163(9): 4985-4993.

22. Collins HL, Bancroft GJ (1992) Cytokine enhancement of complement dependent phagocytosis by macrophages: synergy of tumor necrosis factor- $\alpha$ and granulocyte-macrophage colony-stimulating factor for phagocytosis of Cryptococcus neoformans. Eur J Immunol 22(6): 14471454.

23. Reed SG, Nathan PIHL DL, Rodricks P, Shanebeck K, Conlon PJ, et al. (1987) Recombinant granulocyte/macrophage colony stimulating factor activates macrophages to inhibit Trypanosoma cruzi and release hydrogen peroxide. J Exp Med 166(6): 1734-1746.

24. Denis M (1991a) Tumor necrosis factor and granulocyte macrophagecolony stimulating factor stimulate human macrophages to restrict growth of virulent Mycobacterium avium and to kill virulent M. avium: killing effector mechanism depends on the generation of reactive nitrogen intermediates. J Leuk Biol 49(8): 380-387.

25. Blanchard K, Michelini Norrids MB, Pearson CA, MCMillen S, Djeu JY (1991) Production of Granulocyte-macrophage colony-stimulating factor (GM-CSF) by monocytes and large granular lymphocytes stimulated with Mycobacterium avium-M. intracellulare: activation of bactericidal activity by GM-CSF. Infect Immun 59(7): 2396-2402.

26. Denis M (1991b) Modulation of Mycobacterium lepraemurium Tumor 
necrosis factor and granulocyte macrophage-colony stimulating factor stimulate human macrophages to restrict growth of virulent Mycobacterium avium. J Leuk Biol Res 22: 205-212.

27. Singer vermes LM, MC Ciavaglia, Kashino SS, Calich VLG (1992) The source of growth-promoting factor(s) affects the plating efficiency of Paracoccidioides brasiliensis. J Med Vet Mycol 30(3): 261-264.

28. Fava netto C, Vegas VS, Sciannamea IM, Guarnieri DB (1969) Antígeno polissacarídico do Paracoccidioides brasiliensis: Estudo do tempo de cultivo do P. brasiliensis necessário ao preparo do antígeno. Rev Inst Med Trop São Paulo 11: 77-81.

29. Boyum A (1968) Isolation of mononuclear cells and granulocytes from human blood. Isolation of monuclear cells by one centrifugation, and of granulocytes by combining centrifugation and sedimentation at $1 \mathrm{~g}$. Scand J Clin Lab Invest suppl 97: 77-89.

30. Pick G, Keisari A (1980) A simple colorimetric method for measured of hydrogen peroxidase produced by cells in culture. J Immunol Methods 38(1-2): 161-172.

31. Pick E, Mizel D (1981) Rapid microassay for the measurement of superoxide and hydrogen peroxide production by macrophage in culture using an automatic enzyme immunoassay reader. J Immunol Meth 46(2): 211-226.

32. Green LC, Wagner DA, Glogowski J, Skipper PL, Wishnok JS, et al. (1982) Analysis of nitrate, nitrite, and [15N] nitrate in biological fluids. Anal Biochem 126(1): 131-138.

33. Carmo JPM, Peraçoli MTS, Calvi SA, Dias LA, Rodrigues DR, et al. (2001) Inhibition of human monocyte oxidative burst by virulent strain of Paracoccidioides brasiliensis. Rev Soc Bras Med Trop 34(II): 143-144.

34. Sasada M, Kubo A, Nishimura T, Kakita T, Moriguchi T, et al. (1987) Candidacidal activity of monocyte-derived human macrophages: relationship between Candida killing and oxygen radical generation by human macrophages. J Leuk Biol 41(4): 289-294.

Creative Commons Attribution 4.0

International License

For possible submissions Click Here
35. Lehn M, Weiser WY, Engelhorn S, Gillis S, Remold HG (1989) IL-4 inhibits $\mathrm{H}_{2} \mathrm{O}_{2}$ production and anti leishmanial capacity of human cultured monocytes mediated by IFN- $\gamma$. J Immunol 143: 3020-3024.

36. Vazquez Torres, Jones Carson A, Balish J (1995) Peroxynitrite contributes to the candidacidal activity of nitric-oxide producing macrophages. Infect Immun 64(8): 3127-3133.

37. Denis M (1994) Human monocytes/macrophages: NO or no NO? J Leuk Biol 55(5): 682-684.

38. Moncada S, Higgs A (1993) The L-arginine nitric oxide pathway. N Engl J Med 329(27): 2002-2012.

39. Alspaugh JA, Granger DL (1993) Inhibition of Cryptococcus neoformans replication by nitrogen oxides supports the role of these molecules as effectors of macrophage-mediated cytostasis. Infect Immun 59(7): 2291-2296.

40. Moreira AP, Peraçoli MTS, Dias LA, Martins M, Calvi SA, et al. (2001) Killing of Paracoccidioides brasiliensis by peritoneal macrophages activated by IFN- $\gamma$ or TNF- $\alpha$ is mediated by $\mathrm{H}_{2} \mathrm{O}_{2}$ and NO. Rev Soc Bras Med Trop 34(II): 145.

41. MaCKmicking J, Xie Q Nathan C (1997) Nitric oxide and macrophage function. Annu Rev Immunol 15: 323-350.

42. Albina JE (1995) On the expression of nitric oxide synthase by human macrophages. Why no NO? J Leuk Biol 58(6): 643-649.

43. Djeu JY, Blanchard DK (1987) Regulation of human polymorphonuclear neutrophils (PMN) activity against Candida albicans by large granular lymphocytes via release of a PMN-activating factor. J Immunol 139I(8): 2761-2767.

44. Blanchard DK, Norris BM, Djeu JY (1991) Production of Granulocyte macrophage colony-stimulating factor by large granular lymphocytes stimulated with Candida albicans: role in activation of human neutrophil function. Blood 77(10): 2259-2265.

\section{Your subsequent submission with Crimson Publishers will attain the below benefits}

- High-level peer review and editorial services

- Freely accessible online immediately upon publication

- Authors retain the copyright to their work

- Licensing it under a Creative Commons license

- Visibility through different online platforms

- Global attainment for your research

- Article availability in different formats (Pdf, E-pub, Full Text)

- Endless customer service

- Reasonable Membership services

- Reprints availability upon request

- One step article tracking system 